K A N D A I

\begin{tabular}{|l|l|r|}
\hline Volume 17 & No. 2, November 2021 & Halaman 256-279 \\
\hline
\end{tabular}

\title{
IDENTITAS BUDAYA DAN PRADOKSAL KULINER TRADISIONAL DALAM CERPEN KETIKA SAATNYA DAN KISAH-KISAH LAINNYA (Cultural Identity and Traditional Culinary Paradoxal in the Short Story Ketika Saatnya dan Kisah-Kisah Lainnya)
}

\author{
Puji Retno Hardiningtyas \& Ni Nyoman Tanjung Turaeni \\ Balai Bahasa Provinsi Bali \\ Jalan Trengguli I No. 34 Denpasar Timur, Bali, Indonesia \\ Pos-el: ruwetno@yahoo.co.id
}

(Diterima: 20 September 2020; Direvisi: 13 April 2021; Disetujui: 2 Oktober 2021)

\begin{abstract}
The formulation of the research problem is how literature combines culture, especially Bugis food and culinary delights; local culinary image is juxtaposed with modern food from abroad in a collection of short stories Ketika Saatnya dan Kisah-Kisah by Darmawati Majid. The data of this research are food and culinary-themed texts, namely six short stories entitled "Tentang Hal yang Membawamu ke Sebuah Warung Coto di Pinggiran Kota pada Hari Sekitar Pukul 10 Pagi", "Ningai", "Kiriman dari Inggris", "Passampo Siri", "Nasu Likku", and "Kak Sulaeman". The research data collection used the literature study method with the note-reading technique, which is to create a direct and indirect conversation corpus. Data analysis used an analytical descriptive method with critical interpretative techniques. The theory used in this research is Tobin's gastronomy. The results and discussion of this study indicate that first, literature and gastronomic aspects, namely the art of cooking and serving food, are cultural elements of the Bugis ethnic community. Second, there is an element of paradox and ambiguity when juxtaposing the image of traditional Bugis culinary delights and foreign culinary delights - foreign drinks - which can be felt by the characters in the short story. The two research results reinforce the presence of the image of Bugis traditional culinary and the image of foreign food which has a more practical and cleaner way of serving - as a form of discourse and the struggle for the power of the post-colonial nation's existence. Thus, through culinary literature, it can be a space for the presence of subaltern groups in the context of the regional culture of the Nusantara.

Keywords: culture, culinary literature, postcolonial, short stories, traditional food
\end{abstract}

\begin{abstract}
Abstrak
Rumusan masalah penelitian ini adalah bagaimana sastra meramu budaya, khususnya makanan dan kuliner khas Bugis; citra kuliner lokal disandingkan dengan makanan modern dari luar negeri dalam kumpulan cerpen Ketika Saatnya dan Kisah-Kisah Lainnya karya Darmawati Majid. Data penelitian ini adalah teks cerita bertema makanan dan kuliner, yaitu enam cerpen berjudul "Tentang Hal yang Membawamu ke Sebuah Warung Coto di Pinggiran Kota pada Hari Sekitar Pukul 10 Pagi", "Ningai", "Kiriman dari Inggris", "Passampo Siri”, "Nasu Likku”, dan "Kak Sulaeman”. Pengumpulan data penelitian digunakan metode studi pustaka dengan teknik baca catat, yaitu mencatat korpus percakapan langsung dan tidak langsung. Analisis data digunakan metode deskriptif analitik dengan teknik interpretatif kritis. Teori yang digunakan dalam penelitian ini adalah gastronomi Tobin. Hasil dan pembahasan penelitian ini menunjukkan bahwa pertama, sastra dan aspek gastronomi, yaitu seni memasak dan menyajikan makanan merupakan unsur budaya masyarakat suku Bugis. Kedua, adanya unsur paradoksal dan ambiguitas ketika menyandingkan citra kuliner tradisional Bugis dan kuliner luar negeri-minuman luar negeri-yang dapat dirasakan para tokoh dalam cerpen tersebut. Kedua hasil penelitian memperkuat kehadiran citra kuliner tradisional Bugis dan citra makanan luar negeri yang memiliki cara penyajian lebih praktis
\end{abstract}


dan lebih bersih-berbanding terbalik sebagai bentuk wacana dan pertarungan kuasa keberadaan bangsa pascakolonial. Dengan demikian, melalui sastra kuliner dapat menjadi ruang hadirnya kelompok subaltern dalam konteks kebudayaan daerah Nusantara.

Kata-kata kunci: budaya, sastra kuliner, pascakolonial, cerita pendek, makanan tradisional

DOI: $10.26499 / j k . v 17 i 2.2811$

How to cite: Hardiningtyas, P. R. \& Turaeni, N. N. T. (2021). Identitas budaya dan pradoksal kuliner tradisional dalam cerpen Ketika Saatnya dan Kisah-Kisah Lainnya. Kandai, 17(2), 256-279 (DOI: 10.26499/jk.v17i2.2811)

\section{PENDAHULUAN}

Isu hangat tentang kuliner dan budaya sangat membawa pengaruh besar dalam dunia sastra dunia dan di Indonesia. Senyampang dengan hal itu, kehadiran karya sastra yang mengangkat tema budaya, khususnya kuliner marak ditulis sastrawan di Indonesia saat ini. Namun, sebelumnya sajian kuliner dalam karya klasik di Indonesia pun sudah banyak dituliskan oleh sastrawan pada kala itu, misalnya dalam karya adiluhung Serat Centhini/Suluk Tambangraras atau Tambangraras-Amongraga (R.N. Ranggasutrasna, R.N. Yasadipura II, dan R.N. Sastradipura, 1742 tahun Jawa/1814 M). Pada dekade 2000-an, sastrawansastrawan Indonesia yang menulis karya bertajuk kuliner, seperti Dee (Dewi Lestari) dalam cerpennya Filosofi Kopi (2006) dan novel Madre (2011). Selain itu, sastrawan lain yang menyajikan kuliner dalam karyanya adalah Nukila Amal berjudul "Smokol" (cerpen pilihan Kompas, 2009), Teenlit Resep Cherry (2008) dan Resep Cinta (2007) karya Primadona Angela, Centhini: 40 Malam Mengintip Sang Penganti (Suardian Wirodono, 2009), Chicklit: Selera Gorgia karya Jenny Nelson (fiksi Amerika, terjemahan Siska Yuanita, 2012), dan novel kuliner Off the Record (Ria S.W., 2018). Novel Indonesia lainnya yang tidak kalah fenomenal berkisah tentang kuliner adalah Aruna dan Lidahnya (Laksmi Pamuntjak, 2014), Pulang (Leila S. Chudori, 2012), dan Coffe Memory (Riawani Eltya, 2013). Sementara itu, kumpulan cerpen Ketika
Saatnya dan Kisah-Kisah Lainnya (Darmawati Majid, 2019) sebagai sumber data penelitian memuat 13 cerita dan 6 di antara mengisahkan perjalanan tokoh antara cinta, kenangan, dan makanan suku Bugis dan makanan minunan bangsa Barat (Inggris). Sebagai gambaran awal penelitian ini, sastra kuliner menjadi penting ketika mengangkat identitas kultural sekaligus menjadi promosi kuliner Nusantara.

Artikel ini disajikan untuk melihat gejala sastra kuliner yang memengaruhi identitas kultural masyarakat Bugis yang menunjukkan jejak poskolonial tokohtokohnya yang bersentuhan dengan makanan Barat. Dengan sendirinya, tokoh-tokohnya membentuk mimikri, hibriditas, dan ambivalensi terhadap cita rasa makanan Nusantara, terutama makanan masyarakat Bugis-Makassar. Objek material penelitian ini adalah kumpulan cerpen Ketika Saatnya dan Kisah-Kisah Lainnya karya Darmawati Majid. Adapun alasan dasar penelitian ini adalah sebagai berikut. Pertama, kumpulan cerpen Ketika Saatnya dan Kisah-Kisah Lainnya sebagian ceritanya tergambar sastra kuliner yang membandingkan identitas budaya masyarakat dengan cita rasa makanan. Kedua, cerpen Ketika Saatnya dan KisahKisah Lainnya mengandung budaya kuliner masyarakat Bugis yang tepat dikaji dengan perspektif gastronomi. Ketiga, cerpen Ketika Saatnya dan KisahKisah Lainnya ditemukan kesederhanaan masyarakat Bugis dalam menyajikan kuliner Nusantara disandingkan sikap tokoh atas ambivalensi mencari identitas 
asli di tengah makanan asing dan global dari luar negeri.

Berdasarkan alasan penelitian tersebut, rumusan masalah penelitian ini adalah (1) bagaimana sastra meramu budaya, khususnya makanan dan kuliner khas Bugis; (2) citra kuliner lokal disandingkan dengan makanan modern dari luar negeri dalam kumpulan cerpen Ketika Saatnya dan Kisah-Kisah Lainnya karya Darmawati Majid. Tujuan penelitian ini adalah (1) mendeskripsikan dan menginterpretasi sastra kuliner dalam cerpen; (2) menentukan pembacaan gastronomi dalam fenomena sastra kuliner di Indonesia.

Sebagai bahan bandingan dengan penelitian sebelumnya, kajian pustaka yang membahas sastra kuliner dan teori gastronomi pernah dilakukan oleh Zamzuri (2019), Anggraeni (2019), Budiyanto dan Latifah (2018), Artika (2017), Nitami (2016), Bramantio (2013), dan Utami (2012). Artikel "Membongkar Ideologi "Dapur" Hasta Indriyana melalui Gastrocriyicism" tulisan Zamzuri (2019) ini membahas kuliner dalam puisi Rahasia Dapur Bahagia karya Hasta Indriyana. Penelitian ini menjelaskan boga/kuliner yang berkaitan dengan kesenangan, memori masa lalu, dan seni dengan pendekatan semiotika. Lima puisi karya Hasta Indriayana yang menggambarkan bagian "dapur", yaitu "Ngaliwet", "Oseng Genjer", "Sayur Lodeh", "Sayur Batang Talas", dan "Warisan Kliping Ibu" sebagai petunjuk simbol dan tanda kuliner dalam dapur menjadi sebuah ruang kerinduan yang ingin disambangi kembali.

Anggraeni (2019) dalam artikelnya berjudul "Novel Seet Nothings: Denganmu, Tanpamu Karya Sefryana Khairil Kajian Gastrocriticism" ini dirumuskan masalah hubungan antara jalinan cerita, makanan, dan kehidupan antartokoh; bagaimana fungsi makanan antartokoh; dan menjelaskan fungsi gastronomi sastra pada deskripsi makanan dalam novel Sweet Nothings: Denganmu, Tanpamu. Penelitian ini mengungkapkan bahwa makanan sebagai penghubung antara jalinan cerita dengan kehidupan para tokoh, makanan memiliki delapan fungsi (makanan sebagai produk pencaharian, pembuka dalam pembicaraan, pengenalan identitas, pengingat masa lalu, mempererat banyak orang, meningkatkan kebersamaan, ekspresi rasa, dan asupan nutrisi) dalam novel, kegunaan makanan sebagai penambah keindahan atau estetika cerita, dan makanan berguna sebagai ekspresi sastra.

Budiyanto dan Latifah (2018) menulis artikel berjudul "Ambiguitas Aruna dan Paradoksal Cita Rasa Lidahnya Poskolonialitas Novel Kuliner Laksmi Pamuntjak". Masalah yang diangkat artikel tersebut adalah warisan poskolonial yang dipahami melalui mimikri, hibriditas, dan ambivalensi sikap tokoh terhadap kuliner lokal dan Barat. Dalam novel Aruna dan Lidahnya ditemukan bahwa sastra menghadirkan kuliner; sikap tokoh yang menggambarkan semangat baru selera lama dalam menilai makanan lokal dan Barat; adanya ambiguitas dan paradoksal sikap tokoh yang melakukan mimikri, mockery sehingga memunculkan pembalikkan pola pikir terhadap selera dan cita rasa kuliner lokal dan Barat. Kajian pustaka ini menjadi acuan dalam pembahasaan pada artikel ini untuk membandingkan temuan sastra kuliner dalam cerpen Ketika Saatnya dan KisahKisah Lainnya. Tidak jauh berbeda dengan kajian pustaka sebelumnya, Artika (2017) menulis artikel berjudul "Novel Aruna dan Lidahnya Karya Laksmi Pamuntjak: Perspektif Gastrocriticism". Masalah penelitian ini difokuskan pada makanan sebagai objek cerita dan bahan kritik terhadap kuliner bangsa Barat dan Timur. Hasil temuan 
yang dilakukan Artika (2017) ini adalah makanan sebagai kesenangan, makanan sebagai bricolage (seni), makanan dan asal-usul penamanaan makanan, dan makanan dan sejarah makanan sebagai identitas budaya masyarakatnya. Masih sejalan dengan kajian sebelumnya, Nitami (2016) juga membahas novel Aruna dan Lidahya yang berjudul "Obsesi Tokoh Utama terhadap Makanan dalam Novel Aruna dan Lidahnya Karya Laksmi Pamuntjak". Topik pembahasan ini difokuskan pada obsesi tokoh utama terhadap makanan. Hasil yang ditemukan dalam penelitian tersebut adalah obsesi tokoh utama dalam menikmati makanan didasari enam faktor, yaitu status yang masih sendiri, sumber kebahagiaan, sarana pembebasan diri, faktor pekerjaan, gaya hidup, dan latar belakang pendidikan.

Artikel lain yang membahas gastronomi ditulis oleh Bramantio (2013) melakukan penelitian berjudul "Sastra dan Kuliner: Evolusi Gastronomi ke Gastrosofi dalam Tiga Cerpen Indonesia". Ketiga cerpen yang menjadi objek materi adalah "Filosofi Kopi", "Madre", dan "Smokol" yang menggambarkan sebuah puitika dalam sajian kuliner. Hasil yang ditemukan dalam tiga cerpen tersebut adanya sihir kopi yang disimbolkan sebagai kesempurnaan dan kesadaran personal. Selain itu, tiga cerpen itu menunjukkan hibriditas, lintas generasi, dan penulisan ulang sejarah yang dinarasikan dalam tokoh-tokohnya. Dalam cerpen "Smokol" ditemukan wajah Indonesia pada semesta meja makan yang tercermin melalui tokokhnya. Hal yang paling penting dari artikel ini adalah tiga cerpen menghadirkan makanan dan minuman atau kuliner sebagai fokus cerita yang dikemas dalam pemahaman filosofi masyarakatnya, baik dalam makanan, peralatan makan, maupun peralatan masak, gambaran gastronomi menjelma sebagai gastrosofi. Utami (2012) meneliti "Mimikri dalam Kajian Kuliner melalui Kajian Poskolonial", dengan melihat mimikri dalam kuliner Indonesia yang menempatkan budaya bangsa yang terjajah. Artikel ini objek langsung adalah makanan/kuliner Indonesia, baik kuliner tradisional maupun nontradisional. Hasil temuannya adalah makanan Barat menjadi anutan dalam kuliner di Indonesia. Makanan sebagai bagian dari kebudayaan, tidak luput dari mimikri pada masa kolonial Hindia Belanda.

Beberapa artikel yang sudah terbit sebelumnya, menyajikan unsur gastronomi dalam karya Indonesia atau luar negeri dengan fokus pada makanan dan peran tokoh-tokohnya mendapatkan bahan makanan, memperoleh dan mengolah makanan, dan tata cara mengonsumi makanan. Untuk kajian tentang cerpen serupa pernah ditulis oleh Hardiningtyas (2019) berjudul "Performativitas gender dalam Ketika Saatnya dan Kisah-Kisah Lainnya". Dari beberapa artikel tersebut, perbedaan penelitian ini dengan penelitian sebelumnya adalah pembahasan indentitas budaya masyarakat Bugis dan bagaimana penerapan kritik gastronomi Ronald Tobin dengan melihat jejak kolonial yang menciptakan mimikri, hibriditas, dan ambivalensi terhadap cita rasa makanan masyarakat BugisMakassar-bangsa Timur-dan bangsa Barat.

\section{LANDASAN TEORI}

Untuk menganalisis cerpen ini digunakan teori poskolonial dan pendekatan gastronomi Tobin. Wacana kolonial dalam artikel ini merujuk teori Edward W. Said tentang orientalisme. Menurut Said (2010), orientalisme dipahami sebagai wacana kolonial yang memperlihatkan antara "terjajah" atau bangsa Timur dan "penjajah" atau bangsa 
Barat. Lebih saksama lagi, Said (2010) perpendapat bahwa orientalisme mempertegas kedudukan diri (the self) dan Liyan (other) yang menjadi pemikiran poskolonial. Dengan kata lain, kebudayaan Eropa memperoleh kekuatan dan identitasnya dengan cara mempertentangkan dirinya terhadap dunia Timur sebagai pelindung, bahkan sebagai "diri" (the self) yang tersembunyi.

Kontruksi kolonial Barat ataupun Timur dapat diberi pemaknaan bermacam-macam, bahkan bisa bertentangan. Penerapan gaya hidup, pola pikir, dan kebudayaan Indis yang dilakukan masyarakat terjajah terhadap model kehidupan yang ditawarkan wacana kolonial, identifikasi masyarakat terjajah terhadap Barat, tidak berarti kepatuhan masyarakat terjajah terhadap penjajahnya. Pada tingkatan makna, tindakan masyarakat terjajah untuk meniru (to mimic) menjadi ejekan (mockery) terhadap penjajah karena pribumi tidak sepenuhnya meniru dengan setia model yang ditawarkan penjajah (Bhabha, 1994; Faruk, 2007). Menurut Ashcroft (2003), "berbeda" dalam hal ini subjek poskolonial adalah bahwa seseorang dapat disebut sebagai "Sang Lain". "Sang Lain" yang dimaksudkan adalah seseorang yang berwujud (tubuh) menjadi alat perjuangan melawan penindasan; tubuh juga merupakan simbol perjuangan dan kesempatan bagi penjajah untuk mengontrol, dan bagi terjajah untuk memiliki identitas. Pandangan tentang "Sang Lain" memberikan peniruan yang dilakukan pribumi atas penjajah Belanda bukan melalui bahasa, melainkan lebih banyak melalui gaya hidup. Titik persinggungan antara mempelajari Eropa dan kultur kolonial adalah kelas interpreter, yakni kelas yang dibedakan atas penggolongan rasial, etnik, dan status sosial di masyarakat. Di samping itu, muncul yang dinamakan sebagai peniruan yang secara tidak langsung merupakan ejekan bagi pribumi dan kolonial itu sendiri.

Di pihak lain, menurut Bhabha, mimikri kolonial adalah suatu hasrat dari subjek yang berbeda menjadi subjek "Sang Lain" yang hampir sama, tetapi tidak sepenuhnya. Konsep mimikri Bhabha ini mengandung ambivalensi karena di satu sisi kaum pribumi ingin membangun identitas persamaan dengan kaum penjajah, sedangkan mereka juga mempertahankan perbedaannya. Mimikri muncul sebagai representasi dari perbedaan, yaitu perbedaan tersebut merupakan proses pengingkaran. Yang dimaksudkan ambivalensi mimikri, yaitu pertama, mimikri adalah suatu strategi yang rumit untuk menata kembali, mengatur, mendisiplinkan, dan mencocokkan "Sang Lain" sebagai visualisasi kekuatannya; kedua, mimikri juga merupakan ketidakcocokan, sebuah perbedaan atau perlawanan yang melekat pada fungsi strategis kekuatan dominasi kolonial. Pada praktiknya, mimikri juga mengusung paham mockery (mengejek), tetapi juga memperolok-olok. Sikap memperolok-olok ini juga merupakan suatu cara pribumi untuk mengidentifikasikan dirinya dengan kaum penjajah, antara masyarakat kecil dan penguasa (1994). Dari pandangan tersebut, dapat disimpulkan bahwa dampak hubungan yang hibrid dan ambivalensi pribumi adalah mimikri, bahkan mockery terhadap pertemuan budaya Barat dan Timur. Teori ini digunakan untuk menganalisis bentuk mimikri dan mockery yang dilakukan tokoh terhadap masakan lokal/Nusantara dan masakan Barat.

Dalam perspektif gastrocriticism atau gastronomic literary studies diihat sebagai cara pandang untuk membedah hubungan antara budaya dan makanan. Secara sederhana, menurut Counihan \& Esterik (2013), "food and culture studies have somehow made interdisciplinarity 
workable. Sotimes co-opting, more often embracing the history and geography of food as part of the holistic emphasis of anthropology, food studies have become increasingly sophisticated theoretically" (hlm. 1). Dari pendapat tersebut dapat disimpulkan bahwa kajian tentang makanan dan budaya entah bagaimana telah membuat interdisipliner dapat diterapkan. Sering kali kooptasi, lebih sering merangkul sejarah dan geografi makanan sebagai bagian dari penekanan holistik antropologi, studi makanan menjadi semakin canggih secara teoretis. Sejalan dengan itu, Montanari (2006) berpendapat bahwa

"Food is culture when it is produced, even "performed" because man does not use only what is found in nature (as do all the other animal species) baut seeks also to create his own food, a food specific unto himself, superimposing the action of production on that of predator or hunter.

Terjemahan:

"Makanan adalah budaya ketika diproduksi, bahkan "dipertunjukkan" karena manusia tidak hanya menggunakan apa yang ditemukan di alam (seperti yang dilakukan semua spesies hewan lainnya) tetapi juga berusaha untuk menciptakan makanannya sendiri, makanan khusus untuk dirinya sendiri, melindungi dirinya dari predator atau pemburu.

Harris (1998) juga berpendapat bahwa hal lain itu adalah tradisi gastronomi masyarakat, budaya makanan masyarakatnya. Kemudian, Kittler, Sucher, \& Nelms (2020) berpendapat sama bahwa "Food is os essential to ethic, religious, and regional identity that dietary descriptions must be as objective as possible to to prevent inadvertent criticism of the underlying culture".
Pendapat tersebut dimaknai bahwa makanan sangat penting untuk etika, agama, dan identitas regional sehingga deskripsi makanan harus seobyektif mungkin untuk mencegah kritik yang tidak disengaja terhadap budaya yang mendasarinya.

Konsep dasar kajian gastrokritik sastra adalah boga dan kuliner dalam karya sastra. Salah satu cara memandang perlakuan Halligan terhadap makanan adalah dengan melihatnya sebagai gastrokritik. Salah satu pelopor bidang ini adalah kritikus Prancis Ronald Tobin. Pada November 2008 ia memberikan kuliah di UCSB berjudul "Thought for Food: Literature and Gastronomy" yang membahas istilah gastro-kritik. Sejalan dengan hal itu, Tobin (2008) berpendapat bahwa

"Although anthropologists and sociologists have seen food as an interplay between cultures and people, says Tobin, literary critics have devoted few pages to the study of selfnourishment in literature until recently. Although Tobin's focus is on comedy in Molière, he indicates the extensive use of food in literature from Homer onwards and identifies the commonality of expressions related to food, but which have also other connotations such as hunger, desire, consummation. The sharing of a meal, biblical breaking of bread and communion, all typify the transformation of food into something else, and are frequently expressive of joy and pleasure."

Terjemahan:

"Meskipun antropolog dan sosiolog telah melihat makanan sebagai interaksi antara budaya dan orang, kata Tobin, kritikus sastra telah mengabdikan beberapa halaman untuk mempelajari makanan mandiri dalam sastra sampai saat ini. Meskipun fokus 
Tobin adalah pada komedi di Molière, ia menunjukkan penggunaan ekstensif makanan dalam literatur dari Homer dan seterusnya dan mengidentifikasi kesamaan ekspresi yang terkait dengan makanan, tetapi yang juga memiliki konotasi lain seperti kelaparan, keinginan, penyempurnaan. Berbagi makan, memecahkan roti dan perjamuan menurut Alkitab, semuanya melambangkan transformasi makanan menjadi sesuatu lain, dan sering kali mengekspresikan kegembiraan dan kesenangan."

Mengacu pada novel abad ke-19 dan ke-20, dia berbicara tentang bahasa masakan sebagai "dokumen zaman". Mengutip Rousseau; "Membaca sambil makan selalu merupakan fantasi saya" suatu bentuk etiket yang dianggap tidak dapat diterima secara sosial". Gastrokritisme dengan demikian juga mengungkap kebodohan etiket (Ronning, 2011).

Kritik poskolonial dalam pembahasan sastra melihat budaya yang dihasilkannya. Sebagai kerangka kritik, poskolonial mengkritisi cara kerja ideologi kolonial (penjajah) dan antikolonial (terjajah) yang pada akhirnya masyarakat terjajah melakukan mimikri, hibriditas, dan ambivalensi sendiri. Menurut Alvarez (2018), "Food has always been a fundamental tool in the process of colonization. Arguably, one cannot properly understand colonization without taking into account the issue of food and eating". Dengan kata lain, makanan telah selalu menjadi sebuah alat pokok dalam proses kolonisasi. Lebih saksama lagi, Alvarez (2018) menjelaskan bahwa melalui urusan makan dan makanan dapat dijadikan dasar pemahaman tentang kolonisasi. Kolonial Eropa merupakan superioritas dibentuk melalui makanan. Sejalan dengan pendapat tersebut, Earle (2012) berpendapat bahwa "Orang Eropa menemukan perkebunan pertanian serupa di seluruh wilayah. Namun, bagi penjajah makanan ini di bawah standar dan tidak dapat diterima untuk makanan yang tepat bagi tubuh orang Eropa. Pada saat penaklukan, makanan Eropa pada dasarnya terdiri atas roti, minyak zaitun, "daging", dan anggur. Sementara diet ini agak dipertahankan dalam perjalanan sebenarnya dari Eropa ke Amerika, pada saat kedatangan, orang Eropa mendapati diri mereka tidak memiliki makanan yang mereka anggap perlu untuk bertahan hidup. Ketika orang Eropa mulai sekarat di negeri-negeri "baru" ini, fokus perhatian bergeser ke makanan. Faktanya, Columbus sendiri yakin bahwa orang Spanyol sekarat karena mereka kekurangan "makanan Eropa yang sehat". Di sini dimulai wacana kolonial tentang "makanan yang benar" (makanan Eropa yang unggul) versus "makanan yang salah" (makanan Pribumi yang lebih rendah). Orang Spanyol menganggap bahwa tanpa "makanan yang benar", mereka akan mati atau, lebih buruk lagi, dalam pikiran mereka, mereka akan menjadi seperti orang pribumi."

Dari beberapa pandangan pakar tersebut, hubungan antara kuliner dan kebudayaan masyarakatnya sangat lekat dan tidak dapat dipisahkan satu dengan lainnya. Dengan menyebut sastra yang mengangkat tema dunia kuliner tidak lepas dari konsep grastronomi yang menarik untuk dikaji lebih mendalam pada karya sastra Indonesia, yaitu kumpulan cerpen Ketika Saatnya dan Kisah-Kisah Lainnya. Penelitian ini menerapkan kajian poskolonial dengan perspektif gastronomi dalam hubungannya dengan budaya sebagai identitas dan kuliner masyarakat BugisMakassar. 


\section{METODE PENELITIAN}

Penelitian ini adalah jenis penelitian kualitatif. Data dikumpulkan dengan metode studi kepustakan dengan teknik membaca cerita pendek dan memilah secara selektif cerita yang bertema atau subtema tentang kuliner/makanan atau bahan seputar makanan, cara mengolah/memasak, cara menyajikan, cara mengonsumsi, dan makanan yang berhubungan dengan mata pencaharian dan budaya. Data cerpen penelitian ini merupakan materi utama, yaitu berupa teks cerpen Ketika Saatnya dan Kisah-Kisah Lainnya karya Darmawati Majid (2019). Data dikaji dengan mengombinasikan pendekatan gastronomi dan teori poskolonial. Langkah pertama yang dilakukan adalah melihat dimensi makanan/kuliner dalam teks karya sastra (cerpen) dan unsur budaya masyarakat Bugis dengan menggunakan pendekatan gastronomi. Kedua, pembacaan atas paradoksal teks sastra dalam konteks cita rasa kuliner tradisonal versus kuliner modern dari negara Barat yang dilihat dari teks cerpen (narasi dan percakapan) yang menyebutkan refleksi paradoksal perbedaan budaya Timur dan Barat. Data dianalisis dengan metode deskriptif analitik dengan teknik pemahaman interpretatif terhadap teks cerpen dengan perpektif gastronomi yang memfokuskan pada masalah yang disajikan dalam penelitian ini.

\section{PEMBAHASAN}

Pada subbab pembahasan ini diuraikan dua hal, yaitu hasil penelitian dan pembahasaan penelitian. Hasil penelitian ini ditemukan enam cerpen yang bertema kuliner/boga dan identitas budaya masyarakat Bugis dan juga makanan/minuman negara Barat. Untuk pembahasan disajikan enam cerpen dengan pembahasaan sesuai dengan rumusan masalah dalam penelitian ini. Kedua subbab tersebut diuraikan dengan saksama berikut ini.

\section{Gastronomi dalam Struktur Enam Cerpen}

Dari tiga belas cerpen Ketika Saatnya dan Kisah-Kisah Lainnya yang diterbitkan tahun 2019 ini, ditemukan enam cerpen yang menyuguhkan tema budaya Bugis, boga masyarakat Bugis, dan makanan negara Barat. Daftar lengkap enam cerpen tersebut dapat dilihat dalam tabel berikut ini.

Tabel 1

Cerpen Bertema Budaya dan Kuliner Karya Darmawati Majid

\begin{tabular}{|c|c|c|c|}
\hline \multirow{2}{*}{ Judul Cerpen } & \multicolumn{3}{|c|}{ Unsur Cerita Pendek } \\
\hline & Tema & Komponen Gastronomi & Halaman \\
\hline $\begin{array}{l}\text { Letupan "Tentang } \\
\text { Hal yang } \\
\text { Membawamu ke } \\
\text { Sebuah Warung Coto } \\
\text { di Pinggiran Kota } \\
\text { pada Hari Sekitar } \\
\text { Pukul 10 Pagi" }\end{array}$ & $\begin{array}{l}\text { Pergulatan seorang perempuan } \\
\text { berpendidikan dalam } \\
\text { menyikapi rumah tangga yang } \\
\text { dilihatnya di warung coto. }\end{array}$ & $\begin{array}{l}\text { Memuat narasi bagaimana } \\
\text { menyajikan makanan coto } \\
\text { Makassar, cita rasa, aroma, } \\
\text { memilih bahan coto, cara } \\
\text { mengolah, dan cara } \\
\text { mengonsumsi coto. }\end{array}$ & $1-12$ \\
\hline "Ningai" & $\begin{array}{l}\text { Kisah cinta lelaki yang tidak } \\
\text { terungkap karena banyak } \\
\text { pertimbangan. }\end{array}$ & $\begin{array}{l}\text { Kisah seorang lelaki yang } \\
\text { duduk di kafe menikmati } \\
\text { secangkir kopi, cita rasa kopi, } \\
\text { dan jenis kopi. }\end{array}$ & $23-32$ \\
\hline
\end{tabular}




\begin{tabular}{l|l|l|l}
\hline $\begin{array}{l}\text { "Kiriman dari } \\
\text { Inggris" }\end{array}$ & $\begin{array}{l}\text { Cita-cita seorang perempuan } \\
\text { yang ingin melihat negara } \\
\text { Inggris. }\end{array}$ & $\begin{array}{l}\text { Tokoh dari Bugis } \\
\text { mengonsumsi teh dari Inggris, } \\
\text { coklat, bagaimana kemasan } \\
\text { teh dari Inggris, dan cara } \\
\text { menyeduhnya. }\end{array}$ & $33-42$ \\
\hline "Passampo Siri" & $\begin{array}{l}\text { Adat yang mewajibkan } \\
\text { seorang perempuan menikahi } \\
\text { lelaki yang tidak dicintai } \\
\text { sebagai pengganti passampo } \\
\text { siri keluarga besar. }\end{array}$ & $\begin{array}{l}\text { Kisah bangsawan yang } \\
\text { menikmati kretek, makan } \\
\text { ikan, dan makan khas Bugis, } \\
\text { seperti dange. }\end{array}$ & 50 -61 \\
\hline "Nasu Likku" & $\begin{array}{l}\text { Perjuangan seorang } \\
\text { perempuan dalam } \\
\text { pertarungannya menyajikan } \\
\text { makanan khas Bugis. }\end{array}$ & $\begin{array}{l}\text { Mengisahkan perempuan } \\
\text { Bugis tengah menyajikan } \\
\text { makanan khas nasu likku, } \\
\text { menyiapkan bahan, cara } \\
\text { memasak/mengolah; } \\
\text { menyedikan makan jadi, } \\
\text { seperti sapi lada hitam; dan } \\
\text { cara mengonsumsi makanan. }\end{array}$ & $62-68$ \\
\hline "Kak Sulaeman" & $\begin{array}{l}\text { Kehidupan melaut mencari } \\
\text { kilang di laut ketika mencari } \\
\text { ikan. }\end{array}$ & $\begin{array}{l}\text { memilih ikan, dan mengolah } \\
\text { ikan. }\end{array}$ & $69-74$ \\
\hline
\end{tabular}

Keenam cerpen tersebut memiliki tema beragam, tetapi sajian budaya dan boga dikemas secara terstruktur oleh pengarangnya sehingga cerpen terlihat seperti paket lengkap. Cerpen "Tentang Hal yang Membawamu ke Sebuah Warung Coto di Pinggiran Kota pada Hari Sekitar Pukul 10 Pagi" berkisah tentang tokoh perempuan bernama Indah, seorang berpendidikan sehingga di sinilah letak tanggung jawab perempuan berpendidikan. Cerpen "Ningai" bercerita tentang tokoh Ningai (hlm. 24; 25) yang dihadapkan dengan tokoh laki-laki yang menjadi feminis dan melakolis dalam menghadapi kisah percintaannya. Dalam cerpen "Ningai", tokoh Kak Amir yang menjadi tokoh kedua merekam jejak tokoh Ningai dengan segala aktivitasnya. Segala hal yang dilakukan tokoh sentral diketahuinya dengan detail oleh tokoh ketiga (Hardiningtyas, 2019). Sementara itu, cerpen "Kiriman dari Inggris" berkisah tentang tokoh Surianti-Antiyang memiliki cita-cita ingin pergi ke Inggris, tetapi apa daya ia harus menjadi seorang istri menikahi laki-laki yang tidak dicintainya, bernama Daeng (hlm. 40-41). Cerpen "Passampo Siri" mengisahkan perjalanan tokoh Andi Ira yang harus menikahi lelaki bukan pilihannya. Cerpen "Nasu Likku" melukiskan tokoh bernama Nurma yang ingin sekali menyajikan makanan khas Bugis yang dikenal dengan nasu likku, tetapi tidak kunjung berhasil seperti yang ia janjikan kepada Danu, suaminya. Terakhir, cerpen "Kak Sulaeman" bertutur tentang sosok Kak Sulaeman yang dinaratifkan menjadi orang kedua dalam cerpen tersebut, Kak Sulaeman yang hilang ditelan ombak saat melaut bersama Ambo.

Secara umum, cerpen-cerpen karya Damawati Majid banyak menggunakan fokalisator eksternal, tampak pula pada cerpen-cerpen "Nasu Likku", "Kak Sulaeman", "Uang Panaik", "Ketika Saatnya", dan "Puang Biccu". Subjek fokalisasi menjadi eksternal atau internal ketika ada peristiwa yang dihadirkan pengarang dari dalam dan luar cerita. Terlepas dari gambaran fokalisasi paratokohnya, dari keenam cerpen tersebut, narasi tokoh utama yang melakukan kontak budaya dan terlibat dalam menyajikan masakan adalah perempuan. Tokoh laki-laki yang terlibat 
dalam menyajikan masakan ditemukan dalam cerpen "Tentang Hal yang Membawamu ke Sebuah Warung Coto di Pinggiran Kota pada Hari Sekitar Pukul 10 Pagi" sangat jelas tokoh Daeng Raga, penjual coto Makassar sebagai latar dan konflik yang dibangun tokoh perempuannya.

\section{Sastra Kuliner dan Identitas Budaya Bugis dalam Cerpen}

Kumpulan cerpen Ketika Saatnya dan Kisah-Kisah Lainnya berusaha keras mempermasalahkan keberadaan manusia dengan gaya cerita yang dari narasinya dikonstruksi sedemikian rupa sehingga jelas posisi pembaca, posisi karya, dan posisi pengarang (Hardiningtyas, 2019). Dari sudut pandang teori pascastruktural, budaya pop, kehidupan masyarakat bekas jajahan, perbedaan gender, dan tinggirendahnya kultur yang mengatur kedudukan status sosial masyarakat. Berikut ini uraian sastra dan dunia kuliner masyarakat Bugis sebagai bentuk identitas sosial dan budaya lokal yang seharsunya dijaga dan dilestarikan.

Berbagai aspek tentang makanan dalam enam cerpen Ketika Saatnya dan Kisah-Kisah Lainnya secara umum dinarasikan oleh pengarang dengan gambaran tempat, masyarakat Bugis, dan budaya masyarakat Bugis. Dalam enam cerpen tersebut, dituturkan pula sumber daya alam, sumber bahan makanan yang ada di sekeliling tokoh, dan bagaimana tokoh mendapatkan bahan serta mengolahnya menjadi santapan yang lezat. Cerita awal yang dibahas berjudul "Tentang Hal yang Membawamu ke Sebuah Warung Coto di Pinggiran Kota pada Hari Sekitar Pukul 10 Pagi" yang menyajikan latar warung coto Makassar, memilih bahan membuat coto, memasaknya, dan menyajikan untuk pelanggan. Komponen gastronomi cerpen ini terletak pada narasi di awal cerita yang mengatakan bahwa warung coto Makassar berada di pinggir kota. Dengan demikian, tempat atau sumber makanan berada di warung coto Makassar di pinggir kota, berikut ini kutipannya.

Siapa pun pasti sulit mendebat anggapan tak ada coto Makassar seenak buatan Daeng Raga di pinggiran kota. Ada yang bilang, itu karena kayu bakar dan kuali tanah liat yang ia pakai menjadikan rasanya istimewa (Majid, 2019).

Dari kutipan tersebut, dapat ditemukan bahwa tempat di pinggiran kota menawarkan makanan khas Makassar yang terkenal, yaitu coto. Coto adalah makanan kebanggaan masyarakat Makassar yang berasal dari Kerajaan Gowa sejak tahun 1538. Makanan coto ini awalnya dibuat oleh pengawal kerajaan (Dabir, 2018; Susanto, Banindro, \& Yulianto, 2019). Sebagai alat atau sarana yang menambak rasa enak coto jika dimasak di dalam kuali dari tanah liat atau korong butta atau uring butta dan direbus dengan kayu bakar. Penamaan makanan coto sendiri adalah sebuah proses perubahan makanan dari tingkat sederhana menjadi lebih kompleks. Dari asal-usul katanya, makanan coto ini adalah makanan yang biasa dikonsumsi di daerah Makassar. Coto ini juga disebut dengan coto Mangkasara, sebenarnya coto tidak jauh berbeda dengan jenis soto di Nusantara lainnya, tetapi yang membedakan adalah bumbu rempah kacang untuk membuat kental kuahnya dan bahan jeroan sapi. Selain itu, ada 40 rempah yang digunakan untuk membuat coto Makassar, umumnya masyarakat Bugis menyebutnya ampah patang pulo (Dabir, 2018; Susanto, Banindro, \& Yulianto, 2019). Pengarang sendiri dalam cerpen ini mampu menjelaskan bahwa kekhasan makanan coto Makassar ini sangat berbeda dengan soto lainnya. Coto Makassar ini sangat diminati karena rasa, 
tekstur, aroma, dan bumbu rempah yang lengkap sesuai dengan selera masyarakat Bugis. Dengan demikian, kebiasaan makanan khas Makassar ini, umumnya tidak berubah meskipun masyarakat etnis Bugis pindah ke daerah lain.

$$
\text { Cerpen "Passampo Siri" ini }
$$
menunjukkan identitas budaya dan kebiasan masyarakat Bugis melalui makanan khas Bugis yang terbuat dari tepung sagu diberi campuran kelapa dan gula merah, lalu dibakar dalam cetakan khusus. Makanan legenda ini lebih menitikberatkan mitos pada zaman dahulu yang masih dipercayai oleh masyarakat Bugis hingga sekarang.

"Kak, tidak boleh makan dari penutup, nanti kakak jadi passampo siri". Saat itu, kami tengah menikmati kue dange panas dan aku mengambil penutup panci, benda terdekat yang bisa kujangkau (Majid, 2019).

Dari kutipan tersebut, makanan dange mampu menunjukkan dan mengenalkan identitas seseorang. Makanan ini berasal dari masyarakat Bugis, khususnya di Luwu Timur. Makanan ini dibuat dengan menggunakan cetakan dari tanah liat yang berbentuk kotak-kotak atau cetakan dari almunium. Makanan dange beraroma khas sagu basah dan ini disajikan bersama makanan lain, seperti ikan masak, ikan kuah, dan sayuran berkuah. Dalam konteks lokal budaya Bagis Makassar sajian makanan legenda ini sebagai nilai yang mendasari identitas sosial masyarakat Bugis. Dari contoh cerpen ini dapat disimpulkan bahwa makanan mampu menunjukkan identitas seseorang dan masyarakatnya. Identitias merupakan suatu bentuk konstruksi sosial yang menjadi makna dan pengamalam manusia. Menurut Mattulada (1985), orang Bugis-Makassar dalam kehidupan sehari-harinya masih terikat sistem norma dan aturan adat yang dianggap luhur dan keramat. Seperti kutipan ini memperjelas mitos menjadi sebuah kenyataan yang dialami oleh Andi Ida.

"Ah, itu hanya mitos. Logikanya, kan, makan dari panci memang tidak bagus dilihat. Sudah, saya malas ambil piring lagi... (Majid, 2019).

"Tidak apa kalau kakak jadi passampo siri saya nanti?" Passamo siri, dua kata itu membebani kepalaku saat ini. Aku selalu menganggap itu mitos. Tak pernah kubayangkan jika suatu hari, beberapa tahun kemudian, aku betul akan menghadapi situasi ini. Aku harus menggantikan Andi Ira bersanding di pelaminan. Menutup aib keluarga (Majid, 2019).

Kedua kutipan tersebut dengan pendapat Abdullah (1985; Rismawidiawati, 2016) bahwa siri' dalam masyarakat Bugis adalah menyangkut segala sesuatu yang paling peka dalam diri, seperti martabat atau harga diri, reputasi, dan kehormatan yang harus ditegakkan dalam kehidupan keluarga. Sesuai dengan pendapat Said (2010) bahwa konstruksi identitas-Timur atau Barat-hampir selalu melibatkan konstruksi antitesis dari Liyan yang aktualisasinya selalu menjadi objek interpretasi dan reinterpretasi yang berlangsung tanpa henti.

Cerita lain tentang pengumpulan bahan makanan dan cara mengolahnya dapat dilihat dalam cerpen "Kak Sulaeman". Proses pengolahan bahan makanan ikan dan kerang dari hasil melaut dilakukan dengan cara memilah yang segar, lalu yang ikan dan kerang yang kecil dimasak dan dikonsumsi sendiri, sedangkan yang besar dijual. Bagaimana memilah kerang dan ikan dapat dilihat pada kutipan berikut.

Pada waktu lain, dia akan membawaku ke pantai dan mengajari berenang atau 
mencari kerang di tepi laut berlumpur saat air sedang surut. Aku selalu berteriak kegiarangan begitu tongkat bambunya menusuk ke lumpur dan ada cipratan air yang keluar setelahnya, menandakan ada kerang di titik itu. Aku tidak pernah mampu menguasai keahliannya. Aku lebih suka mencari kerang pada celah-celah pohon bakau yang banyak tumbuh di sekitar pantai. Sepulang mencari kerang, hasil tangkapan hari itu separuh kami serahkan kepada Indo dan sisanya kami masak sendiri ... (Majid, 2019).

Kutipan tersebut menggambarkan tokoh laki-laki bernama Kak Sulaeman dan adik perempuannya mencari bahan makanan yang bersumber dari alam, yaitu ikan dan kerang di tepi pantai dan di tengah laut. Tokoh adik perempuan itu sedang mengenang masa lalu ketika Kak Sulaeman masih hidup dan mengajarinya mencari kerang. Pekerjaan nelayan atau melaut adalah berkaitan dengan mata pencaharian untuk memenuhi kebutuhan hidup. Karena masyarakat Bugis tersebar di dataran rendah dan di pesisir, banyak masyarakat yang hidup sebagai petani dan nelayan. Seperti gambaran laki-laki di cerpen "Kak Sulaeman" ini memenuhi kebutuhan hidup sebagai nelayan. Narasi pekerjaan laki-laki bertugas mencari bahan kebutuhan hidup, terutama pemenuhan makanan kepada keluarga. Dengan bekal alat sederhana, seperti tongkat bambu yang digunakan untuk menemukan pusat keberadaan kerang. Alam di pesisir telah menyiapkan banyak makanan berupa binatang yang layak dikonsumsi manusia. Binatang laut, seperti ikan, cumi-cumi, kerang, dan gurita, yang mengandung vitamin dan kandungan lain untuk memenuhi kebutuhan tubuh.

Tata cara memasak makanan khas Bugis juga dinarasikan dalam cerpen
"Nasu Likku". Cerpen ini memperlihatkan bahan baku pembuatan nasu likku dan bagaimana mengolahnya. Tahapan atau proses pembuatan nasu likku dimulai dari pemilihan bahan dasarnya, yaitu ayam kampung dan bumbu rempah lengkap. Sebagai langkah awal pembacaan perhatikan kutipan bahan dasar pembuatan nasu likku dalam cerpen "Nasu Likku" berikut ini.

... Bolak-balik ia bergantian memandangi catatan di selembar kertas dekat penanak nasi dan layar ponselnya yang menampilkan resep masakan. Awalnya, ia pikir resep itu sederhana saja. Semua bahan ia dapatkan dengan mudah di pasar: daging ayam kampung, kelapa, dan lengkuas. Minimarket, yang selalu jadi tempatnya berbelanja bumbu masak instan, tidak diliriknya sama sekali ... (Majid, 2019).

Kutipan tersebut memperlihatkan bahan dasar pembuatan nasu likku, yaitu ayam kampung yang sudah dipotong, santan kelapa, dan lengkuas. Proses pembuatan nasu likku sudah dimulai dengan pemilihan bahan baku ayam kampung yang dipotong-potong sesuai selera dan bumbu rempah yang lengkap dengan parutan lengkuang mendominasi. Nasu likku atau ayam lengkuas adalah makanan khas Makassar yang terbuat dari ayam kampung, santan, dan rempahrempah pilihan-bawang putih, bawang merah, kemiri, jinten, merica, jahe, lengkuas, daun salam, serai, gula merah, dan garam-dicampur dengan rajangan lengkuas yang hampir menutupi seluruh potongan-potongan ayam. (Dabir, 2018; Susanto, Banindro, \& Yulianto, 2019; Barkow, Taslilm, Hadju, Ishak, Attamimi, Silwana, Dachlan, Ramli, \& Yahya, 2001). Sementara itu, melalui tokoh Nurma, refleksi memasak nasu 
likku digambarkan lebih saksama berikut ini.

Ia telah selesai memeras kelapa dari tadi. Perasannya sudah selesai ia tuang ke wajan. Potongan ayam pun sudah ia cuci sampai bersih. Lengkuas belum seluruhnya ia parut karena ragu. Ia menelepon indo-nya sekali lagi sambil melirik jam: pukul 12 lewat 20 menit (Majid, 2019).

Dari kutipan tersebut dijelaskan proses atau cara menyiapkan pembuatan masakan nasu likku, yaitu ayam yang sudah dipotong, santan kelapa, dan lengkuas. Bahan baku ayam kampung dipotong sesuai selera dan dicuci bersih, kelapa diparut dan diperas untuk diambil santannya, dan lengkuas diparut untuk dicampur dalam masakan nasu likku. Tahapan proses pembuatan nasu likku telah dinarasikan pengarang melalui tokoh Nurma dan indo-nya. Sebagai makanan khas suku Bugis, nasi likku sangat tepat sebagai inspirasi certita pendek. Nilai moral yang dapat dipetik dari cerpen ini adalah mengingatkan kepada anak-anak perempuan untuk menjaga resep masakan khas Bugis sebagai warisan keluarga secara turuntemurun. Subtansi cerpen ini sangat mengajarkan bahwa identitas masyarakat Bugis dapat dilihat dari kuliner khas yang terkenal hingga saat ini.

Dari beberapa contoh kutipan cerita Ketika Saatnya dan Kisah-Kisah Lainnya dikisahkan tata cara mencari bahan makanan, cara mengolahnya, dan cara mengonsumsi makanan tradisional masyarakat Bugis. Selain itu, cerpencerpen yang menjadi objek materi analisis penelitian ini memberikan gambaran bahwa identitas masyarakat Bugis atau masyarakat lainnya di Indonesia dapat ditentukan dari jenis kuliner, bagaimana mencari bahannya, memasaknya, dan menyantapnya. Bahkan, alat apa yang digunakan untuk memasak makanan tradisional menjadi salah satu ciri identitas masyarakatnya. Tidak saja pada tata boganya, identitas masyarakat Bugis dalam cerpen-cerpen karya Darmawati Majid ini disisipkan dengan melukiskan nama tokoh, adatistiadat, dan budayanya.

\section{Cita Rasa Kuliner Masyarakat Bugis Versus Kuliner Modern dari Barat}

Proses mimikri dipengaruhi dominasi media terhadap proses hegemoni Barat di era neokolonialime. Bentuk mimikri hasil hegemoni ini yang harus ditanggapi secara positif dalam memperkaya khazanah budaya Indonesia. Sebaliknya, masyakat Indonesia juga harus pandai memfilter adanya perubahan kuliner yang akan berpengaruh kuat dalam pembentukan karakter dan identitas budaya Nusantara. Selain menganggap bahwa makanan Barat atau makanan dari luar negeri lebih enak atau lebih baik daripada makanan lokal atau tradisional, dalam cerpen karya Darmawati Majid ini menunjukkan adanya inferioritas bekas kaum terjajah yang mengejek minunan lokal. Adapun cerpen yang menarasikan mimikri dan mockery minuman asli Indonesia versus Barat dapat dilihat pada kutipan berikut.

Ningai, entah sudah berapa kali kita mendatangi kafe ini berdua ... Kau mengetuk-ngetukan pensil ke cangkir kopi yang baru kau minum setengah (Majid, 2019).

Kutipan tersebut diceritakan dalam cerpen "Ningai". Latar kafe menjadi lokasi tokoh Ningai dan Aku/Amri menikmati kopi modern. Minuman kopi merupakan tren Abad ke-21 ini dihadirkan dengan cara modern. Cita rasa kuliner, minuman modern dari luar negeri jelas berbeda dari segi kemasan dan cara menyajikannya dibandingkan kopi tradisional. Produk kopi yang dijual dan 
disajikan di kafe lebih diminati di pasaran, terutama generasi muda/ produk kopi diambil dari bahan dasar late atau espresso yang diolah menggunakan mesin peracik kopi atau dikenal dengan coffee maker. Berbeda dengan kopi tradisional yang dibuat natural dengan pengeringan sinar matahari dan digoreng tanpa minyak lalu digiling dengan cara sederhana. Cara menyeduhan kopi tradisional pun sagat sederhana, yaitu bubuk kopi direbus dengan api secara langsung atau siapkan kopi dan gula kemudian disenduh dengan air mendidih. Kutipan sebelumnya diperkuat kembali berikut ini yang dinarasikan dalam cerpen "Ningai".

Untuk mendapat perhatianmu, aku ingat pernah menyelipkan salah satu puisi penyair yang suka kupinjam karyanya ke bukumu saat kau pamit ke kamar kecil, tepat setelah kau menyesap kopi latte yang meninggalkan buih di bibirmu-bibir yang hanya berani kucium dalam mimpi. Malam itu berakhir dengan aku berbaring di kamar, menatap langitlangit sambil tersenyum dan terpejam, memegang bibirku yang menyisakan sedikit rasa latte (Majid, 2019).

Kata latte menjadi tanda bahwa jenis minuman ini tidak asli dari Indonesia, terlebih suku Bugis. Tidak dimungkiri jika kopi di Indonesia merupakan minuman yang sudah ada sejak lama, tetapi cara penyajiannya pun berbeda dengan minuman tren seperti kopi latte dalam cerpen tersebut. Meskipun di Indonesia sendiri telah mengalami perubahan dalam menyajikan secangkir kopi, diperjelas lagi dalam cerpen "Ningai" ini menunjukkan produk minuman kopi dengan cita rasa yang memiliki mutu baik, aroma kopi khas, dan harum. Kopi latte memang mendunia dan dapat ditemukan di kafe-kafe di
Indonesia. Untuk secangkir kopi latte sendiri dibuat dengan memperhatikan komposisi: kopi espresso-dari Italiaberaroma kuat yang dicampur dengan susu lalu dipanaskan. Salah satu ciri kopi latte ini adalah meninggalkan busa di bibir atau ada busa di atas kopi. Sayangnya, dalam cerpen "Ningai" tidak dinarasikan dengan lengkap tahapan penyajian kopi latte sehingga resep atau meracik kopi tidak dapat dinikmati dengan jelas. Namun, cerpen "Ningai" ini adalah bukti adanya paradoksal kepada generasi muda yang memandang kuliner Barat, terutama kopi latte, lebih terasa nikmat diminum anak-anak muda langsung di kafe sambil nongkong atau mengerjakan tugas. Tokoh Ningai dan Amri adalah tokoh yang mengalami pergeseran identitas sosial budaya dalam menikmati minuman kopi dari Barat dibandingkan dengan kopi produk lokal.

Tidak jauh berbeda dengan penyajian teh dari Inggris dalam cerpen "Kiriman dari Inggris". Tokoh yang mengungkapkan teh Inggris adalah Surianti/Anti yang sebelum menikah bercita-cita sekolah ke luar negeri. Di Indonesia tidak hanya menghasilkan kopi yang berkualitas baik, tetapi juga menghasilkan teh yang beragam. Minuman teh di Indonesia sudah menjadi budaya tersendiri, tidak jauh berbeda dengan di negara Cina, Jepang, atau Inggris. Teh sudah menjadi minuman yang selalu tersedia di meja makan meskipun tidak ada acara khusus. Minuman teh dapat dikonsumsi tanpa menambahkan gula atau dapat juga dengan tambahan gula. Jika ingin lebih enak menikmati teh dapat tambahkan gula batu yang dapat menghasilkan cita rasa manis. Berikut ini sajian teh dalam cerpen "Kiriman dari Inggris".

Ada kotak lain yang lebih kecil dalam kotak tadi. Beberapa gantungan kunci berbentuk bus berwarna merah, 
gantungan kunci kotak bertuliskan "telephone", dua kemasan panjang yang setelah ia matai lagi berisi coklat, dan lain-lain. Kotak kecil berwarna merah berlogo mawar ia amati. Teh Inggris? Di bawah kemasan coklat tadi, ternyata terselip amplop berwarna putih (Majid, 2019).

Kutipan tersebut menguraikan cokelat dan teh Inggris sebagai makanan modern yang dikemas lebih menarik dibandingkan dengan kemasan asli Indonesia. Seperti yang diceritakan oleh tokoh Hartini, masyarakat Inggris memiliki banyak rasa teh dan mimun teh banyak sekali aturannya berbeda dengan di Indonesia. Berikut ini kutipan gambaran cara dan rasa teh Inggris yang terdapat dalam cerpen "Kiriman dari Inggris".

Kebiasaan orang di sini semakin membuat saya rindu sama kau. Kau dan keluargamu suka sekali minum teh, kan? Kau tahu tidak, cara mereka menikmati secangkir teh merepotkan sekali. Ada waktu tertentu, tata krama, dan satu yang saya anggap lucu, saya tidak pernah tahu kalau mereka punya banyak macam rasa teh! Ini kukirimkan beberapa agar kau paham apa maksudku (Majid, 2019).

Dari gambaran cerpen tersebut, masyarakat Inggris yang memiliki tradisi minum teh yang dikenal dengan afternoon tea. Teh yang diseduh adalah jenis teh hitam atau black tea yang juga dikirimkan tokoh Harini kepada tokoh Surianti/Anti. Sikap fanatisme tokoh Hartini terhadap bangsa lain, ia tinggal di Inggris, tidak diiringi dengan menafikan bangsanya sendiri. Dalam cerpen ini, tokoh Hartini gadis desa di Bone, menetap di Inggris selama delapan tahun, tidak sedikit pun lupa dengan makanan lokal di daerahnya. Sikap positif terhadap teh sajian keluarga Surianti/Anti dibandingkan ia menyajikan teh Inggris. Makanan lokal dihadirkan justru menjadi makanan yang memiliki cita rasa tidak kalah dengan minuman Barat. Cerpen "Kiraman dari Inggris" ini menolak pandangan bahwa orang pribumi akan selalu terobsesi meniru gaya hidup dan menikmati makanan Barat yang ditanamkan sejak kolonial, tidak berlaku dalam kehidupan sekarang yang dialami tokoh-tokohnya.

Untuk penyeduhan teh hitam, masyarakat Inggris melakukan lima langkah. Pertama, dalam menyeduh teh hitam dianjurkan menggunakan teko porselin putih atau poci teh tanah liat. Ukuran teko antara 74 milimeter atau 78 milimeter. untuk penyeduhan teh tidak dianjurkan dalam cangkir langsung. Kedua, perlu memperhatikan rasio teh dan air. Untuk dua gram daun teh diperlukan 100 mililiter air yang dijadikan patokan teh beraroma dan terasa enak. Ketiga, air harus direbus dahulu dengan suhu tidak lebih 85 derajat celcius dan saat menyajikan teh suhu air harus di atas 60 derajat celcius. Keempat, teh hitam didiamkan atau direndam selama enam mint sebelum dituangkan ke dalam cangkir. Kelima, ditambahkan susu dalam teh, tuangkan susu ke dalam cangkir sebelum menuangkan teh panas. Cara penyeduhan teh tersebut tidak ditemukan dalam cerpen "Kiriman dari Inggris", tetapi cara penyajian menurut tokoh Surianti/Anti tanpa memperhatikan tahapan seperti masyarakat Inggris lakukan.

Tapi, ia disergap kebingunan ketika membuka kemasannya. Ada dua belas saset dengan warna berbeda. Ia membaca nama yang berbeda di tiap kemasan. Ia menggeleng-gelengkan kepala sambil menuangkan air yang baru saja ia dididihkan ke dalam cangkir. Satu saset ia celupkan ke dalam cangkir itu (Majid, 2019). 
Dari kutipan tersebut, sangat jelas bagaimana Surianti/Anti menyeduh teh Inggris yang tidak sesuai dengan aturan dalam kemasannya. Satu kotak teh terdiri atas dua belas saset dengan warna yang berbeda ini memberikan gambaran bahwa ada simbol modernitas dalam menyajian teh Inggris. Dua belas saset teh itu tersedia berbagai macam rasa yang tidak biasa dirasakan lidah orang Bugis seperti Surianti/Anti. Bahkan, Daeng, suami Surianti/Anti pun tidak bisa meneguk teh Inggris yang telah diseduh Surianti/Anti.

"Bikinkan saya air panas, ya?" ...

"Oh, tidak usah, ini sudah ada."

Ia baru akan menjawab saat mendengar suaminya berteriak dari dapur. Itu pasti teh dari Har: Bersamaan melangkah dari ruang tengah, ia melihat suaminya menyemburkan teh itu dari mulut.

"Puih, minuman apa ini? Lain-lain rasanya."

"Teh dari Inggris, Daeng. Hartini yang kirimkan"

"Inggris? Pantas saja. Coba kau minum. Suaminya kemudian menyodorkan cangkir itu ke arahnya (Majid, 2019).

Ia menyesap perlahan, sambil memejamkan mata, meniru adegan minum teh dari film yang pernah ia tonton bersama Hartini di sekolah dulu, film yang membuat Hartini bermimpi untuk ke datang kota itu pada suatu hari nanti ... Rasa pahit tiba-tiba semakin memekat di tenggorokannya (Majid, 2019).

Dari dua kutipan tersebut, dapat disimpulkan lidah orang Bugis tidak dapat menerima rasa teh Inggris di lidahnya. Meskipun teh Inggris tergolong teh dengan kualitas mutu tinggi dan kemasan yang bagus, cita rasa pahit tidak dapat dapat diterima lidah. Selain cita rasa banyak rasa itu tidak biasanya dicecap lidah Daeng dan Anti yang terbiasa teh dengan legit dan pekat. Di sinilah, letak mimikri yang tidak dapat dirasakan oleh tokoh dalam cerpen "Kiriman dari Inggris". Kebiasaan minum teh di masyarakat Bugis adalah teh yang pekat dan manis. Cerpen "Kiriman dari Inggris" dapat dinilai bahwa paradigma baru yang paradoksal tentang modernitas mencicipi teh Inggris bertentangan dengan konsep itu sendiri. Tokoh Daeng dan Anti tidak menganggap bahwa modenitas dapat mengalahkan produk budaya lokal, termasuk sajian teh asli Indonesia lebih nikmat dibandingkan dengan teh Inggris.

Dalam kutipan cerpen "Kiriman dari Inggris" ini mengaitkan kuliner lokal, terutama minuman teh, dengan identitas sosial budaya tidak mengalami pergeseran budaya. Sikap Anti dan Daeng lebih menghargai minuman teh lokal dibandingkan teh Inggris. Padahal, aroma harum teh Inggris merupakan simbol berbagai macam varian rasa teh Inggris yang ikonik yang sudah diproduksi sejak 300 tahun, 1658, oleh Thomas Garway, seorang pemilik kedai kopi Tom's Coffeehouse menjual teh di Inggris. Lalu kedai kopi itu dibeli oleh Thomas Twinings. Bisnis teh di Inggris dirintis oleh Thomas Twinings, sejak tahun 1706, yang kini telah populer, termasuk di Indonesia. Mulai tahun 2005, Twinings memperkenalkan teh Everday Tea yang dipasarkan sampai Indonesia dan dapat dikonsumsi sehari-hari. Racikan teh andalan Twinings adalah Earl Grey, teh hitam yang harum segar. Teh kemas yang dengan logo teko tinggi berwarna putih dengan dua cangkir teh kini menjadi sebuah simbol modernitas. Teko atau keramik sendiri muncul setelah penyebaran Yixing Teapot di bagian Westen World (Everage, 2006; Somantri, 2014). Sejalan dengan pendapat tersebut, Klimchuck \& Krasovec (2006) berpendapat bahwa penggunaan teko 
berukuran tinggi biasanya digunakan di negara Eropa, seperti di Inggris pada saat acara afternoon tea keluarga Kerajaan Inggris sejak tahun 1980-an hingga sekarang. Simbol minum teh di sore hari adalah tradisi yang dilakukan oleh masyarakat Inggris sebagai cara mempererat dan menjaga silahturahmi. Teko dan cangkir yang digunakan menjadi ikon sebagai objek utama keberadaan teh sebagai tradisi. Di sinilah, keberhasilan pengarang yang mengangkat kuliner lokal sebagai objek narasi cerpen yang menunjukkan bahwa adanya rasa bangga terhadap kuliner lokal. Cerpen "Kiriman dari Inggris" justru menunjukkan kekontrasan dengan penilaian gastronomi pascakolonial.

Berbeda dengan warga Eropa, masyarakat di Indonesia lebih menyukai teh dengan cita rasa legit dan kental. Legit lebih pada rasa manis, sedangkan kental lebih pekat sesuai dengan filosofi masyarakat Indonesia yang menyukai keaslian yang mampu persahabatan dan persaudaraan dengan tradisi minum teh. Dalam bukunya berjudul Tea Lover's Treasury, James Norwood Pratt, perusahaan dagang Belanda, Dutch East India Company (VOC) adalah yang pertama membawa teh ke Eropa tahun 1610. VOC mempekerjakan puluhan ribu pegawai di berbagai negara jajahannya, salah satunya Indonesia (Somantri, 2014). Menurut Sriyadi, Suprihatini, \& Khomaeni (2012; Somantri, 2014), masyarakat Indonesia sudah menjadikan minuman teh sebagai sebuah tradisi turun-temurun. Tradisi minum memang awalanya hanya dilakukan oleh kalangan bangsawan, kemudian sesuai dengan perkembangan zaman, minum teh sudah menjadi kebisaan masyarakat luas. Teh dikenal pertama kali tahun di Indonesia tahun 1686 ketika Dr. Andreas Cleyer, dari Jerman, membawa tanaman teh ke Indonesia sebagai tanaman hias. Tahun 1782, Pemerintah Belanda mulai membudidayakan tanaman teh, terutama di Pulau Jawa yang didatangkan langsung bijinya dari negara Cina. Sejak saat itu, teh menyebar luas tumbuh di Indonesia, termasuk di Makassar. Namun, bagi masyarakat Bugis, minuman teh adalah bagian dari budaya. Tidak dapat dimungkiri cara yang dilakukan keluarga Anti merupakan tradisi keluarga. Di masyarakat luas suku Bugis, minum teh atau kopi adalah bagian dari kehidupan gotong royong mengangkat rumah dan memumpuk kebersamaan warga dalam tradisi mappalette bola. Tradisi ini dan sajian makanan sebelum pengangkatan rumah tidak disebutkan dalam cerpen "Kiriman dari Inggris".

Pengetahuan lain tentang tata boga masyarakat Bugis adalah makanan khas nasu likku. Makanan yang berbahan baku ayam ini dikisahkan dalam cerpen "Nasu Likku". Dari cerpen ini dapat dilihat bahwa makanan tradisional lebih sulit dan ribet untuk memasaknya. Sebagai makanan khas suku Bugis, nasu likku ini memang kerap kali disajikan ketika acara khusus dan sakral, seperti mappaccing (ritual memoleskan daun pacar kepada calon mempelai adat Bugis-Makassar pada malam sebelum akad nikah dilaksanakan), akikah, dan acara adat lainnya. Sikap Nurma ini sama dengan sikap tokoh Deang dan Surianti/Anti pada cerpen "Kiriman dari Inggris". Anggapan tentang makanan Barat lebih menarik dan lebih nikmat, justru sebaliknya tidak ada pandangan inferior bekas kaum terjajah yang mengejek makanan tradisional atau lokal dalam sikap tokoh Nurma. Tokoh suami Nurma, Danu, yang cenderung bersikap netral untuk menilai makanan lokal dan modern. Nurma sendiri menganggap makanan Barat, seperti sapi lada hitam, lebih praktis dibandingkan makanan lokal yang sulit memasaknya. Meskipun Nurma sangat kewalahan ketika memasak sapi lada hitam, ia tetap 
menyajikan makanan modern itu kepada suaminya.

Sapi lada hitam itu akhirnya berhasil ia masak dua hari kemudian. Meskipun, ia tidak berhasil membuatnya benarbenar hitam (Majid, 2019).

Dari kutipan cerpen tersebut, tidak ada suatu hal yang memperlihatkan sikap dan mentalitas bangsa poskolonial yang sering kali dilakukan peniruan oleh masyarakat pribumi, warga Indonesia. Tokoh Nurma dan Danu lebih netral dalam menghadapi mentalitas mimikri yang meniru, memuja gaya, mengikuti pandangan, dan pola berpikir kolonial, dalam hal ini penilaian terhadap makanan. Sikap netral tokoh Numa dan Danu dapat dilihat dalam kutipan berikut ini.

... Dari ratusan kali itu, tak sekalipun ia menyempatkan diri duduk diam di dapur dan memperhatikan proses memasak sajian sakral itu. Ia hanya menunggu sampai aroma lengkuas yang khas menguar dari dapur dan berakhir ia menjilati sisa-sisa makanan itu di jari-jarinya. Tidak pernah sebelumnya Nurma merasa sangat merindukan dapur kecil ibunya di Bone sana. (Majid, 2019).

Selain nasu likku dan sapi lada hitam, pengarang juga menarasikan cara memasak perkedel kentang. Cara membuat perkedel kentang ini dinarasikan oleh tokoh Nurma dan Danu dalam cerpen "Nasu Likku". Berikut ini kutipan yang tata cara membuat perkedel kentang dalam cerpen "Nasu Likku".

Langkah pertama, kentang ia rebus. Hasilnya keras. Mungkin kebanyakan tepung, pikirnya. Di resep yang lain dikatakan, kentangnya digoreng kemudian diblender dan di beri pala secukupnya. ... ia pun susah payah menumbuk kentang dengan cobek karena mereka belum punya blender. Gagal. Hari berikutnya, ia memutuskan menyisihkan uang belanja untuk memboyong sebuah blender merek terkenal ke dapur mereka. Kini, alat itu bertengger dengan cantik di sisi kompor gas. Hasilnya (Majid, 2019).

Cerpen ini sangat menarik karena mengisahkan tata cara memasak makanan modern. Cara membuat perkedel kentang dengan bahan dasar kentang dan tambahan tepung menjadi lauk yang tepat menemani nasi. Perkedel kentang ini tidak asli makanan dari Indonesia. Perkedel kentang dikenalkan oleh bangsa Belanda yang membawa resep ini ketika menjajah Indonesia. Perkedel berasal dari bahasa Belanda, yaitu frikadeller, tetapi lidah orang Indonesia tidak dapat melafalkan huruf $f$ sehingga menjadi huruf $p$. Dari sejarahnya, perkedel ini adalah makanan populer di Jerman dan negara Eropa lainnya-Denmark, Kepulauan Faroe, Norwegia, Polandia, Rusia, Estonia, Ukraina, Belanda, dan Lithuania yang berbahan dasar kentang dan daging giling. Menurut Soekiman (2011), hidangan yang biasa disajikan dalam rijsttafel yang populer digemari masyarakat di Hindia Belanda tahun 1990-an, di antaranya zwartzuur, hutspot, daging ham dengan kuah, roti, tar, puding, agar-agar (goedir/gudir), perkedel (frikedeller), semur (smoor), rol-lade, sup (soep), biefstuk (bistik), resoulles, aneka minuman es (es puter), mie telur, pilus, ayam panggang kecap, udang goreng, kopi susu, botok udang, kepiting goreng, sambel kelapa, sayur lodeh Semarang, nasi kebuli, sayur menir, sayur lodeh Surabaya, pindang kecap, besengek, ayam lada kecap, gulai kambing, puding, omelet, satai ayam, satai daging, satai kambing, dan serundeng. 
Dari daftar makanan pada masa penjajahan Belanda adalah perkedel kentang. Kebiasaan masyarakat Hindia Belanda, khususnya pribumi bangsawan yang mendapat pengaruh dari bangsa Eropa melakukan mimikri gaya hidup dan pola makanan. Secara umum, perkedel terbuat dari kentang yang digreng atau direbus kemudian dihaluskan dicampur dengan daging cincang atau giling, ditambah irisan daun seledri dan bumbu penyedap rasa. Setelah adonan selesai dihaluskan dengan dcara diulek atau diblender, adonan dibentuk bulat gepeng, sebelum digoreng celupkan ke dalam kocokan telur ayam terlebih dahulu. Tahapan inilah yang tidak dinarasikan dalam cerpen "Nasi Likku" secara detail sesuai dengn buku resep masakan. Cita rasa yang diperlihatkan dalam cerpen adalah rasa perkedel yang terlalu banyak tambahan tepung sehingga alot ketika digigit. Perkedel yang enak adalah yang daging gilingnya terasa di lidah. Dalam hal pengenalan teknologi memasak, cerpen "Nasi Likku" menawarkan standar baru bagi ibu rumah tangga melalui alat menghaluskan bahan atau bumbu masakan, seperti piring, sendok, garpu, kompor gas, panci stainless, ketel air, talenan dan pisau, cobek batu, alat penghancur bumbu, blender, dan kocokan telur (Berkum, 1913; Anggraeni, 2015). Dari penjelasan tersebut, dpat disimpulkan bahwa makanan coto Makassar dan nasu likku merupakan citra makanan lokal yang dibuat dengan bahan lokal yang memiliki kesan tinggi setara dengan makanan luar negeri.

Meskipun Nurma dan Danu mengenal makanan sapi lada hitam dan perkedel sebagai masakan modern, tetapi sikap mereka tidak fanatik terhadap bangsa lain berlebihan. Sebaliknya, sikap mereka justru menjunjung tinggi makanan tradisional dan pandangan masakan lokal perlu dipelajari dan diwariskan kepada generasi muda secara turun-temurun. Kutipan tersebut membuktikan citra positif nasu likku yang ditampilkan dalam cerpen ini sebagai makanan yang khas Nusantara yang layak dilestarikan.

Sikap positif lainnya, juga terlihat pada tokoh Daeng Raga dalam cerpen "Tentang Hal yang Membawamu ke Sebuah Warung Coto di Pinggiran Kota pada Suatu Hari Sekitar Pukul 10 Pagi". Berikut ini cita rasa kuliner khas BugisMakassar diracik dan diperlihatkan bahan daging dan bumbu dapurnya. Berikut ini kutipannya.

Ada juga yang menembak, aroma kuahnya yang khas datang dari racikan kacang mete alih-alih kacang tanah sebagai bahan dasar. Yang lain menyebut Daeng Raga sangat berhatihati memilih daging dan jeroan sapi hingga dia rela tidak berjualan kalau daging dan jeroan yang dijumpainya di pasar tidak memenuhi standar yang teguh dipegangnya. Tapi, ada juga yang mengatakan bahwa kepiawaian Daeng Raga membumbui setiap ceritanyalah yang menarik orang untuk mencicipi jualannya (Majid, 2019).

\section{Bahan makanan coto Makassar memang berbahan dasar daging} berkualitas dan jeroan sapi pilihan seperti narasi tokoh Daeng Raga yang tidak akan berjualan jika bahan yang didapat tidak ditemukan di pasar. Meskipun membeli bahan masakan coto Makassar di pasar, tetap Daeng Raga memperhatikan kualitas daging dan jeroan sapi. Tidak ada kritikan atau penilaian masakan yang dinarasikan dalam cerpen "Tentang Hal yang Membawamu ke Sebuah Warung Coto di Pinggiran Kota pada Suatu Hari Sekitar Pukul 10 Pagi" dan "Nasi Likku". Hidangan makanan kuliner khas Makassar dalam cerpen muncul dan 
dianggap memiliki citarasa adiluhung karena tokoh-tokohnya melakukan ambivalensi yang menempatkan aproari dalam konteks sosial dan budaya masyarakat Bugis. Justru ambivalensi makanan Barat yang identik dengan citaraasa dan sajian yang praktis tidak diminati tokoh dalam cerpen tersebut. Tokoh sendiri tidak dapat melakukan penilaian yang adil ketika menilai rasa minuman/makanan Barat karena sudah ada parameter yang dibentuk oleh "selera asing/Barat" diterapkan untuk mengukur "selera lokal".

Dari beberapa contoh sajian kuliner dalam cerpen karya Darmawati Majid dapat simpulkan bahwa identifikasi pengaruh budaya Eropa terhadap kuliner Indonesia pada dasarnya bergantung pada pergaulan dan mimikri masyarakat itu sendiri. Bahkan, kenyamanan tempat makan juga tidak memengaruhi penilaian cita rasa masakan lokal lebih jelek daripada makanan Barat. Ada kekuatan yang tertanam dalam sikap tokoh-tokoh dalam cerpen Ketika Saatnya dan KisahKisah Lainnya, yaitu sikap menghargai atas kekayaan kuliner Nusantara dengan lidah pribumi dan akan berbeda pula dengan eksperesi tokoh yang mencicipi minuman Barat yang tidak biasa dinikmati sehari-hari.

Bentuk lain pengolahan dan penyajian santapan ikan bakar secara tradisional juga ditemukan dalam cerpen "Kak Sulaeman". Berikut ini kutipan yang menguatkan analisis dari bentuk pengolahan makanan beserta penyajiannya. Berikut ini kutipan yang menunjukkan kehebatan laki-laki dalam memasak ikan bakar.

Pagi ini, ketika suamiku menyiapkan menu ikan bakar untuk santap siang kami, aroma tempurung yang dibakarnya menyentakku ke masa kanak-kanak. Masa ketika aku masih menikmati permainan bola-bola bersama Kak Sulaeman (Majid, 2019).

Narasi kehebatan suami, laki-laki Bugis, dalam mengolah ikan laut dengan membakarnya di atas tempurung kelapa. Arang dari tempurung atau sabut kelapa memberi aroma masakan lebih enak dibandingkan membakar dengan arang kayu. Menurut Mahsun (1991), bahan bakar dari tempurung kelapa, penggunaannya belum berkembang maju sebagaimana dengan potensi tungku dari peralatan modern. Ikan yang dibakar harus memiliki rentang antara segar dan kering. Hal inilah yang dilakukan oleh tokoh suami dalam cerita "Kak Sulaeman", ikan laut dibakar dengan tempurung kelapa dilakukan secara tradisional. Cara tardisional ini justru menghemat penggunaan energi bahan bakar dan limbah dapat ditangani dengan cepat serta tidak mencemari lingkungan. Justru dibakar dengan cara tradisional, ikan laut menjadi nikmat untuk santapan. Berbeda dengan pandangan ambivalensi tokoh yang memang menikmati minuman di kafe dan selera Barat seperti tergambar dalam cerpen "Ningai".

Pembakaran ikan dengan tempurung kelapa secara tradisional memang terkesan kotor. Kategori ideal tempat masak, tempat makan, dan peralatan makan yang serba modern merupakan selera Barat. Tidak dapat dimungkiri bahwa interaksi budaya antara bangsa Eropa-Belanda dan pribumi telah memunculkan budaya Indis. Menurut Soekiman (2011), campuran budaya antara bangsa penjajah dan pribumi disebut dengan kebudayaan Indis. Di Indonesia, kebudayaan Indis tidak terlepas dari pengaruh kebudayaan-peralatan, masakan-yang dapat ditiru oleh perempuan pribumi. Secara nyata, keberadaan bangsa Barat tidak dapat dielakan dari bangsa Timur. Seperti halnya dengan interaksi budaya 
antara Barat dan Timur membawa pengaruh pada kebudayaan, salah satunya kuliner. Cerpen Ketika Saatnya dan Kisah-Kisah Lainnya ini menyajikan keistimewaan makanan suku BugisMakassar disandingkan dengan makanan Barat yang memiliki kuantitas masingmasing berdasarkan gaya hidupnya. Gaya hidup mewah sengaja diciptakan yang mencerminkan status sosial mereka, termasuk identitas menjadi sumber kekuatan bagi pemaknaan diri manusia daripada perannya yang disebabkan oleh proses konstruksi diri dan individualisasi yang melibatkan unsur budaya. Perorangan, kelompok sosial, dan masyarakat Bugis memproses keseluruhan konstruksi materi identitas pembentuk dan penata ulang sesuai dengan struktur sosial dan kuliner khasnya menjadi kekuatan identitas yang tidak dapat dipisahkan dari budayanya. Pengarang justru membalikkan cita rasa kuliner Barat yang adiluhung menjadi nomor dua setelah cita rasa masakan khas Indonesia, terutama makanan suku Bugis-Makassar. Dengan demikian, perspektif gastronomi menjadi ada ketika kuliner, identitas, dan budaya masyarakat Bugis hadir dalam cerpen karya Darmawati Majid.

\section{PENUTUP}

Kumpulan cerpan Ketika Saatnya dan Kisah-Kisah Lainnya karya Darmawati Majid menggambarkan kehidupan masyarakat suku BugisMakassar dan kuliner khas daerah yang mencerminkan karakteristik kehidupan masyarakatnya. Penelitian ini menjawab aspek gastronomi dalam sastra kuliner dan cita rasa makanan tradisional versus makanan Barat. Berdasarkan analisis jenis makanan dan budaya dalam cerpen Ketika Saatnya dan Kisah-Kisah Lainnya karya Darmawati Majid dapat disimpulkan menjadi dua hal sebagai berikut.

Pertama, dari tiga belas cerpen Ketika Saatnya dan Kisah-Kisah Lainnya, enam cerpen bertemakan tata boga atau kuliner atau gastromoni dan identitas budaya masyarakat Bugis yang dikisahkan dengan struktur fiksional yang beragam. Struktur cerita enam cerpen tersebut menggambarkan narasi makanan tradisional dan modern yang dikelompokkan menjadi dua komponen, yaitu (1) cerpen yang menceritakan jenis makanan tradisional masyarakat Bugis, cara mengumpulkan makanan dan cara menyajikan, seperti coto Makassar, dange, nasu likku, ikan bakar yang dikumpulkan dengan cara melaut/sebagai nelayan; (2) cerpen yang menarasikan secara prosedural bahan mentah, tahapan cara mengolah makanan, dan cara mengonsumsi makanan, baik secara tradisi maupun modern. Bagian narasi cerpen-cerpen yang menyajikan dua bentuk itu merupakan identitas dan budaya masyarakat Bugis, Makassar sebagai masyarakat agraris dan melaut.

Kedua, enam cerpen karya Darmawati Majid bertema gastronomi yang menyisipkan pesan moral tentang identitas dan berbagai macam kuliner masyarakat Bugis sebagai bentuk identitas masyarakat tradisional melakukan hibriditas, ambivanlensi, mimikri, dan mockery cita rasa makanan Nusantara versus modern. Makanan coto Makassar, dange, dan nasu likku adalah makanan khas masyarakat Bugis yang menjadi makanan turun-temurun yang patut dilestarikan untuk generasi muda sekarang ini. Sementara itu, makanan luar negeri, seperti kopi, sapi lada hitam, dan teh Inggris menjadi populer di lidah masyarakat sekarang ini merupakan bentuk penjajahan melalui cita rasa kuliner.

Dengan hadir dalam cerpen, tema gastromoni dan identitas budaya dapat 
dijadikan riset untuk melakukan rekonstruksi resep makanan khas atau tradisional di Nusantara menjadi makanan modern tanpa menghilangkan identitas masyarakat pemiliknya. Penelitian ini jauh belum membahas sastra kuliner dengan mengutamakan masalah rekonstruksi resep makanan tradisional masyarakat Bugis. Untuk penelitian selanjutnya, dapat dilakukan pembahasaan tahapan dan proses gastronomi, khususnya sastra bertema memasak dan konstruksi resep masakan Nusantara sehingga dapat sejajar dengan resep dan kuliner modern di dunia.

\section{DAFTAR PUSTAKA}

Abdullah, H. (1985). Manusia Bugis Makassar: Suatu tinjauan histori terhadap pola tingkah laku dan pandangan hidup Manusia Bugis Makassar. Jakarta: Inti Idayu Press.

Alvarez, L. (2018). Colonization, Food, and the Practice of Eating. http://www.africaspeaks.com/rea soning/index.php?topic $=11096 . \mathrm{m}$ sg26206, diakses tanggal 28 Agustus 2020, pukul 14.48 PM.

Anggraeni, D.P. (2019). Novel Sweet Nothings: Denganmu, tanpamu karya Sefryana Khairil kajian gastrocriticism. Jurnal Sapala, 6(1).

Anggraeni, P. (2015). Menu populer Hindia Belanda (1901-1942): Kajian pengaruh budaya Eropa terhadap kuliner Indonesia. Sejarah dan Budaya: Jurnal Sejarah, Budaya, dan Pengajarannya, 9(1), 88--95. http://journal2.um.ac.id/index.ph p/sejarah-danbudaya/issue/view/161
Artika, M.D. (2017). Novel Aruna dan Lidahnya karya Laksmi Pamuntjak: Perspektif gastrocriticism. Bapala, 4(1), 111.

Ashcroft, Bill, Griffiths, Garreth, and Tiffin, Helen. (2003). Menelanjangi kuasa bahasa: Teori dan praktik sastra poskolonial. Terjemahan Fati Soewandi dan Agus Mokamat. The Empire Writes Back: Theory and Practice in Post-colonial Literature. Yogyakarta: Qalam.

Barkow, J.H., Taslilm, N.A., Hadju, V., Ishak, E., Attamimi, F., Silwana, S., Dachlan, D.M., Ramli, \& Yahya, A. (2001). Social competition, social intelligence and why the Bugis know more about cooking than about nutrition. Proceedings of the British Academy, pp. 119--147. Diunduh 30 Agustus 2020. http://publications.thebritishacade my.ac.uk/pubs/proc/files/110p11 9.pdf

Berkum, N.V. (1913). De Hollandsche Tafel in Indie. Gorinchem: J. Noorduyn.

Bhabha, Homi. K. (1994). The Location of culture. London: Routledge.

Bramantio. (2013). Sastra Indonesia: Evolusi grastronomi ke gastrosofi dalam tiga cerpen Indonesia. Jentera, 2(1), 42--55.

Budiyanto, A. \& Latifah, E. (2018). Ambiguitas aruna dan paradoks cita rasa lidahnya poskolonialitas novel kuliner Laksmi Pamuntjak. Jurnal Pendidikan Bahasa dan Sastra, 18(2), doi:10.17509/bs_jpbsp.v18i2.155 510

Counihan, C. \& Esterik, P.V. (2013). Food and culture: A reader. New York: Routledge. 
Dabir, K.A. (2018). Memanjakan lidah di Kota Daeng. Surabaya: CV Pustaka Media Guru.

Earle, R. (2012). The Body of the Conquistador: Food, race and the Colonial experience in Spanish America, 1492-1700. Cambridge: Cambridge University Press.

Everage, L. (2006). Teapots through the ages: A brief history. Diunduh pada 28 Agustus 2020. https://theteaspot.com/media/wys iwyg/news/storyl-d-16.pdf

Faruk. (2007). Belenggu pasca-kolonial hegemoni \& resitensi dalam sastra Indonesia. Yogyakarta: Pustaka Pelajar.

Hardiningtyas, P.R. (2019). Performativitas gender dalam Ketika Saatnya dan Kisah-Kisah Lainnya. Denpost, Minggu, 6 Oktober, hlm. 4.

Harris, M. (1998). Good to eat: Riddle of food and culture. United State of America: Waveland Press.

Kittler, P.G., Sucher, K.P., \& Nelms, M. (2012). Food and culture. Belmont: Wadsworth Cengage Learning.

Klimchuck, M. \& Krasovec, S.A. (2006). Desain kemasan. Jakarta: Erlangga.

Mahsun. (1991). Analisis energi panas tungku ganda bahan bakar Biomassa pada proses pengasapan ikan laut. Skripsi. Malang: Fakultas Pertanian, Universitas Brawijaya.

Majid, D. (2019). Ketika Saatnya dan Kisah-Kisah Lainnya. Jakarta: Gramedia.

Mattulada. (1985). Sejarah, masyarakat, dan kebudayaan Sulawesi Selatan. Ujung Pandang: Hasanuddin Unversity Press.
Montanari, M. (2006). Food is culture. New York: Columbia University Press.

Nitami, N. (2016). Obsesi tokoh utama terhadap makanan dalam novel Aruna dan Lidahnya karya Laksmi Pamuntjak. Dialektika: Jurnal Bahasa, Sastra, dan Pendidikan, 3(1), hlm. 20-35. DOI: http://dx. doi.org/10.15408/dialektika.v3i1. 4182

Rismawidiawati. (2016). Bertahannya bangsawan Luwu (Suatu analisa budaya politik orang Bugis). Patanjala, 8(3), September, hlm. $413-428$.

Ronning, A.H. (2011). Halligan's love affair with food. Coolabah, No. 5, pp. 130-138. Observatori: Centre d'Estudis. Australians: Australian Studies Centre, Universitat de Barcelona.

Said, E.W. (2010). Orientalisme: Menggugat hegemoni barat dan mendudukan timur sebagai subjek. Terjemahan Achmad Fawaid. Yogyakarta: Pustaka Pelajar.

Seokiman, D. (2011). Kebudayaan Indis: dari zaman kompeni sampai revolusi. Jakarta: Komunitas Bambu.

Somantri, R. (2014). The story in a cup of tea. Editor Rani Anriani Koswara. Jakarta: TransMedia Pustaka.

Susanto, J.A., Banindro, B.S., \& Yulianto, Y.H. (2019). Perancangan fotografi makanan tradisonal Makassar "sedap mentong makanang Makassar". Jurnal DKV Adiwarna, 1(14), 19. 
Sriyadi, B., Suprihatini, R., \& Khomaeni, H.S. (2012). The development of high yielding tea clones to increase Indonesian tea production. In Global Tea Breeding: Achievements Challenges, and Prespectives. L.Z. Chen, Z. Apostolides, and Z., Chen (Eds.). Zhejiang: Zhejiang University Press.

Tobin, R. (2008). Thought for food: Literature and gastronomy. Lecture given at University of California Santa Barbara, November (2008). Diakses tanggal 28 Agustus 2020, pukul 16.21 PM.
Utami, S. (2012). Mimikri dalam Kajian Kuliner melalui Kajian Poskolonial. Dalam Prosiding the 4th International Conference on Indonesian Studies: Unity, Diversity, and Future, tanggal 910 Februari 2012.

Zamzuri, A. (2019). Membongkar ideologi "Dapur" Hasta Indriyana melalui Gastrocriticism. Dalam Prosiding Seminar Hasil Penelitian Sastra, tanggal 6-7 November 2019, hlm. 383-396. Semarang: Balai Bahasa Jawa tengah bekerja sama dengan Balai Penelitian dan Pengembangan Agama Semarang dan Badan Perencanaan Pembangunan, Penelitian, dan Pengembangan Daerah Provinsi Jawa Tengah. 